\title{
Five-year survival of patients with chronic systolic heart failure of ischemic and non-ischemic etiology: analysis of prognostic factors
}

\author{
Mateusz Mościński ${ }^{1}$, Bożena Szyguła-Jurkiewicz², Michał Zakliczyński ${ }^{3}$, Piotr Rozentryt ${ }^{2}$, Robert Partyka ${ }^{4}$, \\ Marian Zembala ${ }^{3}$, Lech Poloński ${ }^{2}$ \\ ${ }^{1}$ Cardiology Department, Regional Specialist Hospital No. 4 in Bytom \\ $23^{\text {rd }}$ Chair and Clinical Department of Cardiology, Medical University of Silesia, Silesian Center for Heart Diseases, Zabrze \\ ${ }^{3}$ Chair and Clinical Department of Cardiac Surgery and Transplantation, Medical University of Silesia, Silesian Center for Heart \\ Diseases, Zabrze \\ ${ }^{4}$ Department of Anesthesiology, Intensive Care and Emergency Medicine, Medical University of Silesia, Katowice \\ Kardiochirurgia i Torakochirurgia Polska 2014; 11 (1): 56-62
}

\begin{abstract}
Introduction: Despite advances in pharmacotherapy, electrotherapy and interventional treatment, chronic heart failure (HF) is still associated with poor long-term outcome.

Aim of the study: To determine the death rate and risk factors in patients with HF of ischemic and non-ischemic etiology in five-year follow-up.

Material and methods: Consecutive patients with chronic systolic HF hospitalized in the period 2006-2008 were analyzed retrospectively. Study exclusion criteria were: infections ( $<3$ months before hospitalization), hemodynamically significant valve disease, advanced chronic kidney disease, liver cirrhosis and neoplastic diseases ( $<5$ years before hospitalization).

Results: The analysis encompassed 266 patients divided into two groups: Group A, with HF of ischemic etiology $(n=157)$, and Group B, with HF of non-ischemic etiology $(n=109)$. Mortality was significantly higher in Group A than in Group B (49\% vs. $28.4 \%, p=0.001$ ). The independent risk factors for death in Group A were: New York Heart Association (NYHA) class $(H R=1.81 ; p<0.001)$; concentrations of high-sensitivity C-reactive protein (hs-CRP) $(\mathrm{HR}=1.01 ; p<0.05)$, fibrinogen $(\mathrm{HR}=1.04 ; p<0.001)$ and $N$-terminal prohormone brain natriuretic peptide (NT-proBNP) $(\mathrm{HR}=1.02 ; p<0.001)$; and right ventricular end-diastolic diameter (RVEDd) $(\mathrm{HR}=1.07 ; p<0.01)$. In Group B they were age $(\mathrm{HR}=1.07 ; p<0.05)$ and NT-proBNP concentration $(H R=1.03 ; p<0.001)$.

Conclusions: Mortality was significantly lower in Group $B$ than in Group A. The independent risk factors for death in Group B were age and NT-proBNP serum concentration, whilst in Group A they were NYHA class, serum concentrations of hs-CRP, NT-proBNP and fibrinogen, and RVEDd.
\end{abstract}

Key words: prognostic factors, chronic systolic heart failure.

\section{Streszczenie}

Wstęp: Mimo postępów w leczeniu farmakologicznym, interwencyjnym i elektroterapii przewlekła niewydolność serca (NS) nadal wiąże się z niekorzystnym rokowaniem odległym.

Cel pracy: Określenie częstości występowania zgonów i czynników ryzyka u chorych z NS o etiologii niedokrwiennej i nieniedokrwiennej w okresie 5-letniej obserwacji.

Materiat i metody: Retrospektywnej analizie poddano kolejnych chorych z przewlekłą skurczową NS hospitalizowanych w latach 2006-2008. Kryteriami wyłączenia były: infekcje (do 3 miesięcy przed hospitalizacją), obecność istotnej wady zastawkowej, marskość wątroby, zaawansowana przewlekła choroba nerek oraz choroba nowotworowa (w okresie 5 lat przed włączeniem do badania).

Wyniki: Do analizy zakwalifikowano 266 pacjentów, których podzielono na dwie grupy: grupę A - o etiologii niedokrwiennej $(n=157)$, i grupę $B-o$ etiologii nieniedokrwiennej $(n=109)$. Częstość występowania zgonów była istotnie wyższa w grupie $A$ niż w grupie B (49\% vs. 28,4\%, $p=0,001)$. Analiza wieloczynnikowa wykazała, że niezależnymi czynnikami zwiększającymi ryzyko zgonu w grupie A były: klasa NYHA (HR 1,81; $p<0,001)$, stężenie $w$ surowicy wysokoczutego białka C-reaktywnego (hs-CRP) (HR 1,01; $p<0,05$ ), fibrynogenu (HR 1,04; $p<0,001$ ), $N$-końcowego fragmentu propeptydu natriuretycznego typu $B$ (NT-proBNP) (HR 1,02; $p<0,001)$ oraz wymiar końcoworozkurczowy prawej komory (RVEDd) (HR 1,07; $p<0,01)$, a w grupie $B$ wiek (HR 1,07; $p<0,05)$ i stężenie NT-proBNP (HR 1,03; $p<0,001)$. Wnioski: Częstość występowania zgonów była istotnie niższa w grupie B w porównaniu z grupą A. Niezależnymi czynnikami ryzyka zgonu $w$ grupie $B$ okazały się: wiek i stężenie $w$ surowicy NT-proBNP, natomiast w grupie A: klasa NYHA, stężenie hs-CRP, NT-proBNP, fibrynogenu oraz RVEDd.

Słowa kluczowe: czynniki prognostyczne, przewlekła skurczowa niewydolność serca.

Address for correspondence: dr n. med. Mateusz Mościński, Cardiology Department, Regional Specialist Hospital No. 4 in Bytom, phone: +48 6683771 17, e-mail: moscinski.mateusz@gmail.com 


\section{Introduction}

Despite advances in pharmacotherapy, electrotherapy and interventional treatment, chronic heart failure (HF) is still associated with poor outcome. According to population studies, the five-year mortality in symptomatic HF is approximately $60 \%$ [1]. The ageing of societies, combined with the civilizational development, is conducive to the occurrence of coronary disease, hypertension, arrhythmia, heart valve disease, obesity and depression, all of which increase the risk of HF [2-4]. The prevalence of HF in the general population is $2-3 \%$, whilst in individuals aged 70 80 , it increases to $10-20 \%$ [5]. It is estimated that one in five 40-year-olds, regardless of their gender, will at some stage of their life suffer from symptomatic HF [5]. The disease is becoming an increasingly serious social and economic problem.

\section{Aim of the study}

The aim of the work was to determine the risk factors for a five-year death in patients with HF of ischemic and non-ischemic etiology.

\section{Material and methods}

The clinical data of 328 consecutive patients with chronic systolic HF hospitalized at the Clinical Cardiology Center in the period 2006-2008 were analyzed retrospectively. Included in the study were patients with chronic systolic HF (left ventricular ejection fraction LVEF < 40\%) diagnosed at least 6 months before hospital admission. Study exclusion criteria were: infectious diseases in the previous three months, hemodynamically significant valve disease, liver cirrhosis, advanced chronic kidney disease (eGFR $<30 \mathrm{ml} /$ $\min / 1.73 \mathrm{~m}^{2}$ ), and neoplastic disease.

Data regarding patient history, physical examination, laboratory results, resting electrocardiography, echocardiography and coronary angiography were available for all patients.

The biochemical diagnostics were carried out with the Cobas Integra analyzer (Roche). The concentrations of hs-CRP ( $\mathrm{mg} / \mathrm{l})$ were measured by latex-enhanced immunoturbidimetric assay with a $552 \mathrm{~nm}$ wavelength (Cobas Integra 800; Roche). NT-proBNP concentrations $(\mathrm{pg} / \mathrm{ml})$ were measured by immunochemiluminescence with reagents by ROCHE DIAGNOSTICS (Elecsys 2010, Roche). The estimated glomerular filtration rate (eGFR) was calculated with the MDRD equation. Data concerning long-term follow-up were obtained from the medical documentation of the Cardiology Out-patient Clinic and by telephone contact with the patients or their families.

The endpoint was death from any cause. Sudden cardiac death was defined as death caused by an unexpected circulatory arrest, taking place within one hour of the onset of symptoms. The remaining causes of death were determined by a postmortem examination. The cause of death was classified as unspecified if no sudden cardiac death occurred and no postmortem was carried out.
HF of ischemic etiology was defined as the presence of at least one of the following: 1) a stenotic lesion $\geq 50 \%$ in at least one epicardial coronary artery in coronarography, 2) past myocardial infarction, 3) past percutaneous or surgical coronary artery revascularization. If none of these criteria was met, the HF etiology was classified as non-ischemic. Clinical follow-up started on admission and lasted five years.

\section{Statistical analysis}

The data were collated in a spreadsheet and analyzed preliminarily. The thus verified data were then moved to a statistical program for final analysis. The distribution of qualitative variables was verified with the Shapiro-Wilk test. For the comparison of data between two groups of patients the following were used:

- for data with normal distribution or after normalization: Student's $t$-test for independent data; variance homogeneity was assessed with Levene's test,

- for data with distribution other than normal: Mann-Whitney $U$ test,

- for quantitative variables: $\chi^{2}$ test with Yates continuity correction.

The cumulative survival curves were plotted with the Kaplan-Meier method. The significance of differences between groups was assessed with the logrank test. Data with normal distribution are shown as mean \pm standard deviation (SD). Data with distribution other than normal and ordinal data are presented as median and upper and lower quartiles. Qualitative data are shown as percentages. The multiple factor model was based on Cox regression analysis. The best subset of independent variables was identified with the backward stepwise method. The results are presented as hazard ratio (HR) with a 95\% confidence interval and the level of significance. $P<0.05$ was considered statistically significant. All data were analyzed using the STATISTICA software (Data Analysis Software System), version 10.0 by StatSoft Inc.

\section{Results}

Between January 2006 and February 2008, 328 patients with chronic HF were hospitalized at the Clinical Cardiology Center. Based on the study inclusion and exclusion criteria, 282 patients were qualified for the study, though in 16 cases the long-term follow-up data were incomplete. The final five-year clinical follow-up encompassed 266 patients: 157 with HF of ischemic etiology (group A) and 109 with HF of non-ischemic etiology (group B). The basic patient characteristics by group are presented in Table I.

Figure 1 shows the drugs used by patients during follow-up.

In the five-year follow-up, death occurred in 77 (49.0\%) patients in group A and in 31 (28.4\%) patients in group B. The causes of death are shown in Figure 2.

There were no significant differences between the groups with regard to the frequency of implantation of cardioverter-defibrillators $(15.4 \%$ in group $A$ and $18.9 \%$ in 
Tab. I. Basic patient characteristics by group

\begin{tabular}{|c|c|c|c|}
\hline Parameter & $\begin{array}{l}\text { Group A } \\
(N=157)\end{array}$ & $\begin{array}{l}\text { Group B } \\
(N=109)\end{array}$ & $P$ \\
\hline Age [years] & $57.9 \pm 8.5$ & $46.6 \pm 11.8$ & $<0.001$ \\
\hline Male gender & $140(89.2 \%)$ & $96(88.1 \%)$ & NS \\
\hline HF duration [months] & $37(13-64)$ & $24(9-60)$ & 0.03 \\
\hline NYHA class & $3(2-3)$ & $2(2-3)$ & $<0.001$ \\
\hline Diabetes & 57 (36.3\%) & $12(11.0 \%)$ & $<0.001$ \\
\hline Hypertension & $92(58.6 \%)$ & $46(42.2 \%)$ & $<0.001$ \\
\hline COPD & 18 (11.5\%) & $2(1.8 \%)$ & 0.007 \\
\hline Hypercholesterolemia & $146(93 \%)$ & $43(39.5 \%)$ & $<0.001$ \\
\hline Past MI & $123(78.3 \%)$ & - & - \\
\hline Past PCl & 67 (42.7\%) & - & - \\
\hline Past CABG & $38(24.2 \%)$ & - & - \\
\hline $\begin{array}{l}\text { Cardioverter-defibril- } \\
\text { lator }\end{array}$ & $10(6.4 \%)$ & $2(1.8 \%)$ & NS \\
\hline $\begin{array}{l}\text { Resynchronization } \\
\text { therapy }\end{array}$ & $3(1.9 \%)$ & $0(0 \%)$ & NS \\
\hline QRS duration [ms] & $120.1 \pm 33.2$ & $121.1 \pm 31.1$ & NS \\
\hline $\mathrm{HR}[1 / \mathrm{min}]$ & $83(70-90)$ & $81(66-90)$ & NS \\
\hline LVEF [\%] & $23.7 \pm 6.8$ & $26.2 \pm 7$ & 0.003 \\
\hline NT-proBNP [pg/ml] & $\begin{array}{c}1230 \\
(567-2130) \\
\end{array}$ & $\begin{array}{c}980 \\
(434.5-2030) \\
\end{array}$ & NS \\
\hline $\mathrm{eGFR}\left[\mathrm{ml} / \mathrm{min} / 1.73 \mathrm{~m}^{2}\right]$ & $71.8 \pm 24.7$ & $93.3 \pm 21.3$ & $<0.001$ \\
\hline Sodium [mmol/l] & $135.7 \pm 4.4$ & $136.8 \pm 3.6$ & 0.04 \\
\hline
\end{tabular}

$C A B G$ - coronary artery bypass graft, $H R$ - heart rate, LVEF - left ventricular ejection fraction, MI - myocardial infarction, NYHA - New York Heart Association,

$\mathrm{PCl}$ - percutaneous coronary intervention, $C O P D$ - chronic obstructive pulmonary disease

group B, NS) and resynchronizers (6.4\% in group A and $4.7 \%$ in group B, NS) in long-term follow-up.

Figure 3 shows the Kaplan-Meier cumulative survival curve in groups $\mathrm{A}$ and $\mathrm{B}$.

Tables II and III present selected clinical, echocardiographic and biochemical parameters in groups A and B, respectively, divided by five-year survival and death. Tables IV and $\mathrm{V}$ list the independent prognostic factors in both groups.

\section{Discussion}

Over the last few years, numerous prospective randomized clinical trials and epidemiological and observational

Group A

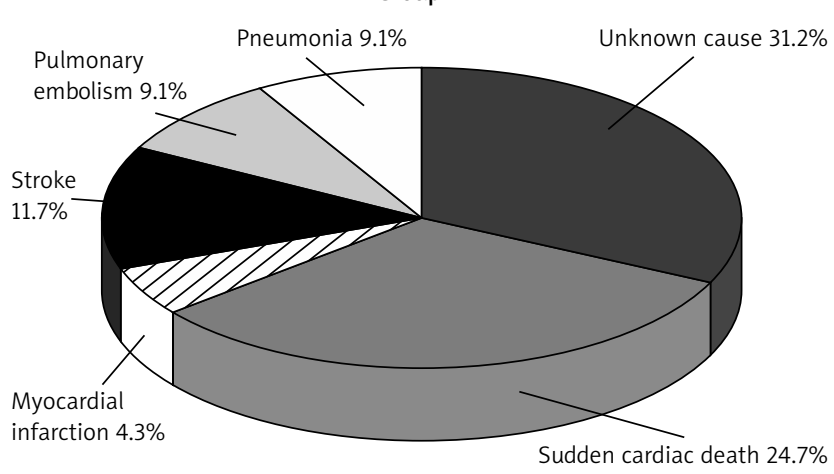

$p<0.001$ $p=0.03$

$p=0.047 \quad p=0.01$

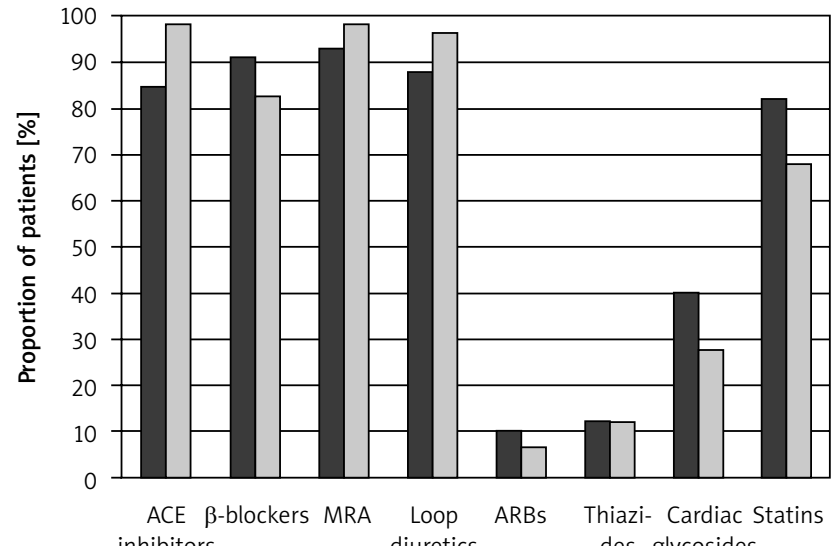

inhibitors diuretics

des glycosides

$12.10 \% \quad 40.10 \% 82.20 \%$

heart failure

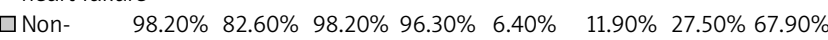
ischemic

heart failure

Fig. 1. Pharmacotherapy in the two groups

studies have been conducted in the population of patients with chronic HF [1, 3, 6-8]. Most analyses, however, encompassed etiologically heterogeneous groups of patients. In our study, we analyzed five-year risk factors for death in consecutive hospitalized patients with chronic systolic HF of ischemic and non-ischemic etiology. The study showed that patients with ischemic HF were significantly older than patients with non-ischemic etiology. This observation is confirmed by large population studies, clinical studies and the POLKARD-HF register [3, 6-8].

Our study showed that concomitant diseases were significantly more frequent in patients with HF of ischemic than non-ischemic etiology. Other studies, such as the EuroHeart Failure Survey and American National Health and Nutrition Survey, also confirmed the high percentage of patients with HF and concomitant diseases $[9,10]$. In the ZOPAN register, one in two HF patients suffered from at least three concomitant diseases [7].

In our study, we observed a low percentage of implantation of cardioverter-defibrillators (ICD) and resynchronizers (CRT). These data were comparable to those from large European registers of HF patients. Analyzing the data from the ESC-HF Pilot Survey 2009-2013, Maggioni et al.

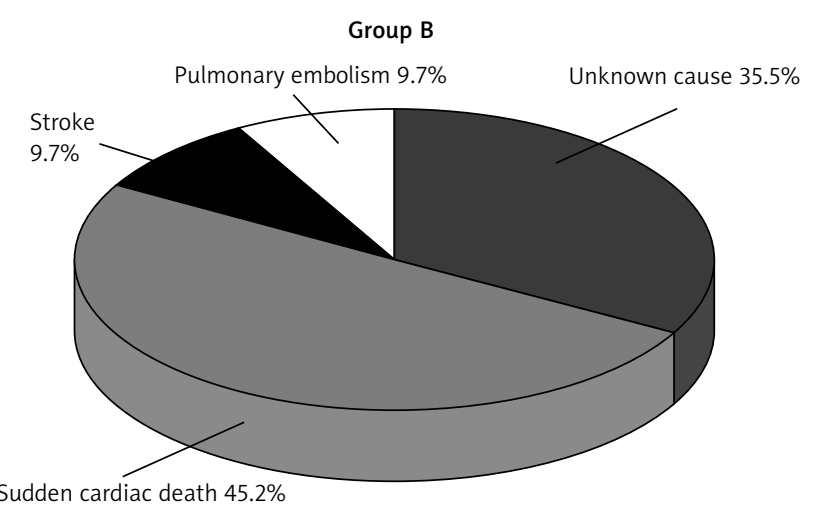

Fig. 2. Causes of death in group A and group B 
concluded that only one in three patients with ICD indications and one in five patients with CRT indications actually underwent device implantation [11].

Also van Veldhuisen et al., based on the analysis of patients recruited to the Eucomed register in 2004-2008, observed a significant difference between the number of patients who, according to the guidelines, qualified for high-energy device implantation and the number of actual implantations [12].

Our analysis showed that the five-year mortality in the studied population was $40.6 \%$ and was higher in patients with ischemic HF. This finding is in consonance with other studies, which showed the outcome in patients with ischemic HF to be worse than in non-ischemic $H F[6,13,14]$. This observation was also confirmed by the results of the MAGGIC meta-analysis, which demonstrated that the ischemic etiology of HF was connected with both a higher risk of death from any cause (HR 1.07) and death from cardiovascular causes (HR 1.11) [14]. Based on their analysis of 534 participants in the Framingham Heart Study, Lee et al. showed that, com-

Tab. II. Basic characteristics of group A, by survival and death

\begin{tabular}{|c|c|c|c|}
\hline Group A & $\begin{array}{l}\text { Survival } \\
(N=80)\end{array}$ & $\begin{array}{l}\text { Death } \\
(N=77)\end{array}$ & $P$ \\
\hline Age [years] & $56.6 \pm 9.0$ & $59.4 \pm 8.4$ & 0.04 \\
\hline HF duration [months] & $24(12-48)$ & $55(16-72)$ & 0.006 \\
\hline NYHA class & $2(2-3)$ & $3(3-4)$ & $<0.001$ \\
\hline LVEF [\%] & $25.9 \pm 7.1$ & $22.1 \pm 6.2$ & $<0.001$ \\
\hline $\mathrm{LA}[\mathrm{mm}]$ & $44.6 \pm 5.7$ & $48.2 \pm 7.2$ & $<0.001$ \\
\hline RVEDd [mm] & $27.4 \pm 4.4$ & $30.0 \pm 5.0$ & $<0.001$ \\
\hline hs-CRP $[\mathrm{mg} / \mathrm{l}]$ & $2.56(1.3-4.11)$ & $\begin{array}{c}4.58 \\
(2.01-12.1)\end{array}$ & $<0.001$ \\
\hline Fibrinogen $[\mathrm{mg} / \mathrm{dl}]$ & $\begin{array}{c}348.5 \\
(324-398.5)\end{array}$ & $\begin{array}{c}456 \\
(376-539.5)\end{array}$ & $<0.001$ \\
\hline NT-proBNP $[\mathrm{pg} / \mathrm{ml}]$ & $\begin{array}{c}567 \\
(403.1-1026)\end{array}$ & $\begin{array}{c}1890 \\
(1230-3240)\end{array}$ & $<0.001$ \\
\hline eGFR $\left[\mathrm{ml} / \mathrm{min} / 1.73 \mathrm{~m}^{2}\right]$ & $80.3 \pm 21.6$ & $64.3 \pm 25.3$ & $<0.001$ \\
\hline Uric acid $[\mu \mathrm{mol} / \mathrm{l}]$ & $417.3 \pm 126.0$ & $471.2 \pm 146.3$ & 0.02 \\
\hline Bilirubin $[\mu \mathrm{mol} / \mathrm{l}]$ & $\begin{array}{c}13.4 \\
(10.8-17.8)\end{array}$ & $\begin{array}{c}17.5 \\
(12.95-25.5)\end{array}$ & $<0.001$ \\
\hline
\end{tabular}

eGFR - estimated glomerular filtration rate, $h s$-CRP-high-sensitivity C-reactive protein, $L A$ - left atrium, LVEF - left ventricular ejection fraction, NT-proBNP $\mathrm{N}$-terminal propeptide of the brain natriuretic peptide, NYHA - New York Heart Association, RVEDd - right ventricular end-diastolic diameter M-mode (diastole)

Tab. IV. Factors affecting the death rate in group A. Results of the multiple factor analysis of Cox proportional hazard

\begin{tabular}{lccc} 
Parameter & HR & $\pm 95 \% \mathrm{Cl}$ & $P$ \\
NYHA class & 1.8136 & $1.2964-2.5370$ & 0.0005 \\
\hline hs-CRP $($ per $1 \mathrm{mg} / \mathrm{l})$ & 1.0139 & $1.0031-1.0249$ & 0.0118 \\
\hline Fibrinogen $($ per $10 \mathrm{mg} / \mathrm{dl})$ & 1.0382 & $1.0162-1.0606$ & 0.0006 \\
\hline NT-proBNP $($ per $100 \mathrm{pg} / \mathrm{ml})$ & 1.0222 & $1.0097-1.0349$ & 0.0005 \\
\hline RVEDd $($ per $1 \mathrm{~mm})$ & 1.0676 & $1.0166-1.1212$ & 0.0088 \\
\hline
\end{tabular}

HR - hazard ratio, hs-CRP-high-sensitivity C-reactive protein, NT-proBNP-

$N$-terminal propeptide of the brain natriuretic peptide, NYHA - New York Heart

Association, RVEDd - right ventricular end-diastolic diameter

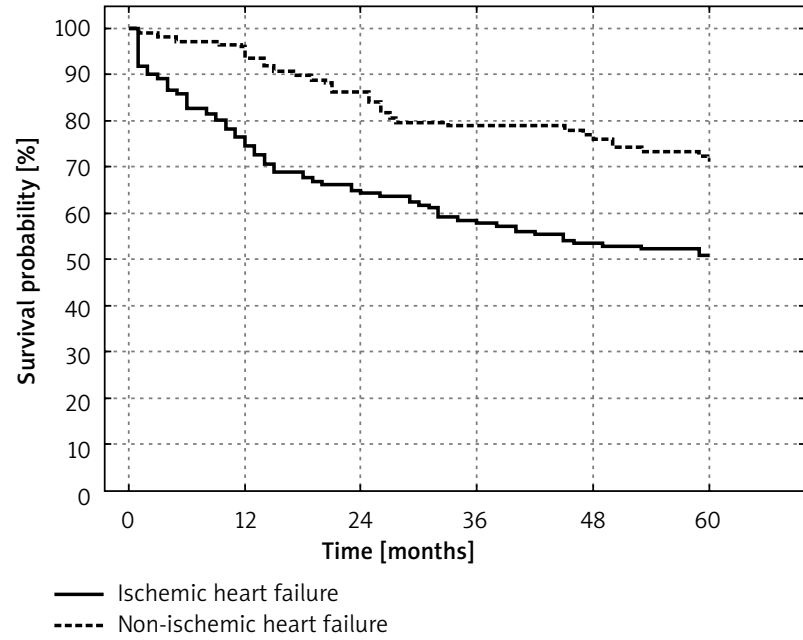

Fig. 3. Kaplan-Meier cumulative five-year survival curve

pared to other etiologies, ischemic HF was associated with the poorest outcome in $3.2 \pm 3.6$ years of follow-up (HR 1.36) [15].

Tab. III. Basic characteristics of group B, by survival and death

\begin{tabular}{|c|c|c|c|}
\hline Group B & $\begin{array}{l}\text { Survival } \\
(N=78)\end{array}$ & $\begin{array}{l}\text { Death } \\
(N=31)\end{array}$ & $P$ \\
\hline Age [years] & $44.8 \pm 11.4$ & $51.3 \pm 11.6$ & 0.02 \\
\hline HF duration [months] & $14.5(7-42)$ & $48(12-60)$ & 0.03 \\
\hline NYHA class & $2(2-2)$ & $2.5(2-3)$ & $<0.001$ \\
\hline Diabetes & $3(3.8 \%)$ & $9(29 \%)$ & $<0.001$ \\
\hline LVEF [\%] & $27.8 \pm 6.9$ & $23.2 \pm 6.7$ & 0.003 \\
\hline RVEDd [mm] & $29.0 \pm 4.9$ & $32.5 \pm 5.4$ & 0.005 \\
\hline hs-CRP [mg/l] & $\begin{array}{c}1.12 \\
(0.74-2.68)\end{array}$ & $\begin{array}{c}3.08 \\
(1.22-5.6)\end{array}$ & 0.04 \\
\hline NT-proBNP [pg/ml] & $\begin{array}{c}745.8 \\
(395.9-1342.5)\end{array}$ & $\begin{array}{c}2067.5 \\
(1116.5-3880.5)\end{array}$ & $<0.001$ \\
\hline $\mathrm{eGFR}\left[\mathrm{ml} / \mathrm{min} / 1.73 \mathrm{~m}^{2}\right]$ & $96.3 \pm 18.5$ & $84.2 \pm 26.8$ & 0.03 \\
\hline Uric acid $[\mu \mathrm{mol} / \mathrm{l}]$ & $418.7 \pm 112.3$ & $489.5 \pm 140$ & 0.03 \\
\hline Bilirubin $[\mu \mathrm{mol} / \mathrm{l}]$ & $\begin{array}{c}16.6 \\
(11.5-21.5)\end{array}$ & $\begin{array}{c}18.5 \\
(14.3-28.8)\end{array}$ & 0.049 \\
\hline
\end{tabular}

eGFR - estimated glomerular filtration rate, hs-CRP - high-sensitivity C-reactive protein, $L V E F$ - left ventricular ejection fraction, NT-proBNP - N-terminal propeptide of the brain natriuretic peptide, NYHA - New York Heart Association, RVEDd - right ventricular end-diastolic diameter M-mode (diastole)

Tab. V. Factors affecting the death rate in group B. Results of the multiple factor analysis of Cox proportional hazard.

\begin{tabular}{lccc} 
Parameter & HR & $\pm 95 \% \mathrm{Cl}$ & $P$ \\
Age & 1.0680 & $1.0095-1.1300$ & 0.0221 \\
\hline NT-proBNP $($ per $100 \mathrm{pg} / \mathrm{ml})$ & 1.0347 & $1.0166-1.0529$ & 0.0001 \\
\hline
\end{tabular}

HR - hazard ratio, NT-proBNP - N-terminal propeptide of the brain natriuretic peptide 
However, several studies present different results. Lourenço et al. followed up 286 patients with $\mathrm{HF}$ of ischemic (38.1\%) and non-ischemic etiology (61.9\%) [16]. The authors found that in the 41-month follow-up there were no significant differences in mortality between the analyzed groups (30.0 vs. $23.2 \%, p=0.258$ ) [16]. It should be noted that no coronarography was performed in a large percentage of the studied patients and that patients with valvular HF were included in the non-ischemic HF group [16]. Korewicki et al. analyzed the mortality in patients from the POLKARD-HF register in a 601-day follow-up period [8]. In $43.2 \%$ of patients, HF was related to coronary disease. The authors observed no significant differences in the outcome in the ischemic and non-ischemic HF groups [8].

In our study, age was an independent risk factor for death in the non-ischemic HF group. In the ischemic group, the risk factors were: NYHA class, serum concentrations of hs-CRP and fibrinogen, and right ventricular end-diastolic diameter. The concentration of NT-proBNP was a risk factor in both groups.

In the study by Allen et al. conducted in a population of patients from the CHARM study, age was also an independent risk factor for death from cardiovascular causes or for hospitalization due to HF exacerbation (HR 1.32 per each 10 years over the age of 60; $p<0.0001$ ) in a follow-up period of 38 months [17]. The independent prognostic value of age for death from any cause was confirmed by the study of Wedel et al. involving patients from the CORONA trial (HR 1.26 per each 10-year increase; $p<0.0001$ ) [18].

These observations are confirmed by the results of Senni et al., where age was a predictor of death or urgent heart transplantation (OR 1.13; 95\% Cl: 1.0-1.4; $p<0.0001$ ) [19].

An elevated NT-proBNP concentration was a risk factor in both groups. In the analysis by Cleland et al. conducted in over 5000 patients with systolic ischemic HF from the CORONA trial [20], the strongest risk factor for death was NT-proBNP concentration expressed as a logarithm. An increase of this parameter by one logarithmic unit was associated with a 1.5-fold increase in the risk of death for any cause [20].

In their analysis of almost 2000 placebo-receiving patients from the Val-HeFT trial, Masson et al. determined the prognostic value of NT-proBNP concentration in two-year follow-up ( $\mathrm{HR}=1.403$ per increase by one logarithmic unit; $p<0.0001$ ) [21]. The prognostic value of NT-proBNP concentration was also confirmed in patients with advanced HF. In the report by Korewicki et al. regarding patients from the POLKARD register, NT-proBNP concentration over 4302 pg/ $\mathrm{ml}$ increased the risk of death or urgent heart transplantation by 1.6-fold [8]. The meta-analysis of eight randomized clinical trials showed that in patients in whom treatment intensity was conditioned by the concentration of natriuretic peptides (RR 0.76; $p=0.003$ ), the risk of death was significantly lower than in patients treated the classical way [22].

$\mathrm{HF}$ is associated with a chronic inflammatory condition [23], whilst its mediators are associated with poorer out- come in HF. In our study, the inflammatory marker (hs-CRP concentration) was an independent risk factor for death in patients with ischemic HF in five-year follow-up. The study by Windram et al. conducted in a group of 957 patients with chronic systolic HF confirmed the value of hs-CRP in the prediction of death in $21 \pm 10$ months of follow-up [24]. Similar to our analysis, patients with infections, tumors and other diseases involving inflammation were excluded from the study [24]. Kozdağ et al. observed that serum concentration of hs-CRP was an independent risk factor for death from cardiovascular causes in $17 \pm 13$ months of follow-up (HR 1.1; $p<0.001)$. Patients with infections were not excluded from the study, a fact that may have affected the results of the analysis [25].

Although the association between fibrinogen and atherosclerotic processes has been well documented, little is known as to its role in HF. In our study, fibrinogen was an independent risk factor for death in patients with ischemic HF. The protein is known to be able to facilitate leucocyte chemotaxis, as well as to stimulate the expression of proinflammatory cytokines which affect cardiomyocyte apoptosis. Additionally, by affecting the endothelial function, it is conducive to atherosclerotic plaque formation [26]. Fibrinogen may also facilitate the creation of thrombi in microcirculation and affect the rheological properties of plasma. This may lead to microcirculatory disorders, which in turn can cause hypoperfusion and recurrent ischemic events [26, 27].

Enlarged right ventricular diameter (RVEDD) was another independent risk factor in the ischemic HF group. Although the assessment of right ventricular diameter is a standard element of the echocardiographic examination, there are few data assessing the prognostic value of this parameter in patients with HF. One of the few studies on the subject was conducted by Meluzin et al. in almost 200 patients [28] with mean left ventricular ejection fraction of $23 \%$, followed up for 16 months. The patients who died had an increased RVEDd more frequently than the patients who completed the follow-up (32 mm vs. $36 \mathrm{~mm}, p<0.05$ ) [28]. In the study conducted by Chrustowicz et al., RVEDd was an independent risk factor for death from cardiovascular causes after mitral valve annuloplasty (HR 1.1; $p=0.04$ ) [29].

Another independent prognostic risk factor in patients with ischemic HF was NYHA class. Gustafsson et al. analyzed the prognostic factors in 4012 consecutive patients hospitalized in 18 Danish clinics [30]. The mortality in 580-day follow-up was $18 \%$, and NYHA class III and IV was an independent risk factor for death or hospitalization (HR 1.32; $p<0.0001)$ [30]. Higher NYHA class was associated with poorer outcome also in the previously cited reports from large clinical trials, such as CORONA, Val-HeFT and CHARM [17-20].

The strength of this study is the long follow-up period of consecutive patients from everyday clinical practice hospitalized at a center with facilities for invasive diagnostics of coronary disease. The angiographic examination of coronary arteries in all patients facilitated patient stratification by disease etiology. Its limitations are the retrospective 
character and the absence of postmortem documentation of the cause of death in a large percentage of cases.

\section{Conclusions}

Risk factors for death in patients with ischemic heart failure are: NYHA class; serum concentrations of fibrinogen, NT-proBNP and hs-CRP; and right ventricular enddiastolic diameter. Risk factors for death in patients with non-ischemic heart failure are age and NT-proBNP serum concentration.

\section{Disclosure}

The authors report no conflict of interest.

\section{References}

1. Bleumink GS, Knetsch AM, Sturkenboom MCJM, Straus SM, Hofman A, Deckers JW, Witteman JC, Stricker BH. Quantifying the heart failure epidemic: prevalence, incidence rate, lifetime risk and prognosis of heart failure. The Rotterdam Study. Eur Heart J 2004; 25: 1614-1619.

2. Wilczek K, Chodór P, Niklewski T, Głowacki J, Przybylski R, Streb W, Krasoń M, Nadziakiewicz P, Trzeciak P, Podolecki T, Kalarus Z, Poloński L. Ocena efektów bezpośrednich i 12-miesięcznego przeżycia po zabiegach balonowej walwuloplastyki aortalnej w krytycznej stenozie zastawki aortalnej u chorych ze schyłkową niewydolnością serca i dużym ryzykiem operacyjnej wymiany zastawki. Kardiochir Torakochir Pol 2012; 1: 16-21.

3. Szymik M, Szyguła-Jurkiewicz B, Partyka R, Spinczyk B, Chudek J, Poloński L. Three-year survival of patients with chronic systoli heart failure due to hypertension: analysis of prognostic factors. Pol Arch Med Wewn 2012; 122: 543-550.

4. Szyguła-Jurkiewicz B, Pudlo R, Samborski K, Muzyk P. Rola depresji w niewydolności serca. Kardiochir Torakochir Pol 2012; 9: 502-506.

5. McMurray JJ, Adamopoulos S, Anker SD, Auricchio A, Böhm M, Dickstein K, Falk V, Filippatos G, Fonseca C, Gomez-Sanchez MA, Jaarsma T, Køber L, Lip GY, Maggioni AP, Parkhomenko A, Pieske BM, Popescu BA, Rønnevik PK, Rutten FH, Schwitter J, Seferovic P, Stepinska J, Trindade PT, Voors AA, Zannad F, Zeiher A; ESC Committee for Practice Guidelines. ESC Guidelines for the diagnosis and treatment of acute and chronic heart failure 2012: The Task Force for the Diagnosis and Treatment of Acute and Chronic Heart Failure 2012 of the European Society of Cardiology. Developed in collaboration with the Heart Failure Association (HFA) of the ESC. Eur Heart J 2012; 33: 1787-1847.

6. Teng TH, Hung J, Knuiman M, Stewart S, Arnolda L, Jacobs I, Hobbs M, Sanfilippo F, Geelhoed E, Finn J. Trends in long-term cardiovascular mortality and morbidity in men and women with heart failure of ischemic versus non-ischemic aetiology in Western Australia between 1990 and 2005. Int J Cardiol 2012; 158: 405-410

7. Rywik TM, Kołodziej P, Targoński R, Fedyk-Łukasik M, Nowicka A, Zinka E, Zbyszyński B, Achremczyk P, Górski J, Muder A, Sadowski J, Leszek P, Kurjata $P$, Broda G, Korewicki J. Characteristics of the heart failure population in Poland: ZOPAN, a multicentre national programme. Kardiol Pol 2011; 69: 24-31.

8. Korewicki J, Leszek P, Zieliński T, Rywik T, Piotrowski W, Kurjata P, KozarKamińska K, Kodziszewska K; Polkard-Hf. Severe chronic heart failure in patients considered for heart transplantation in Poland. Cardiol I 2012; 19: 36-44

9. Wong CY, Chaudhry SI, Desai MM, Krumholz HM. Trends in comorbidity, disability, and polypharmacy in heart failure. Am J Med 2011; 124: 136-143.

10. Cleland JG, Swedberg K, Follath F, Komajda M, Cohen-Solal A, Aguilar JC, Dietz R, Gavazzi A, Hobbs R, Korewicki J, Madeira HC, Moiseyev VS, Preda I, van Gilst WH, Widimsky J, Freemantle N, Eastaugh J, Mason J; Study Group on Diagnosis of the Working Group on Heart Failure of the European Society of Cardiology. The EuroHeart Failure survey programme - a survey on the quality of care among patients with heart failure in Europe. Part 1: patient characteristics and diagnosis. Eur Heart J 2003; 24: 442-463.

11. Maggioni AP, Dahlström U, Filippatos G, Chioncel O, Leiro MC, Drozdz J, Fruhwald F, Gullestad L, Logeart D, Metra M, Parissis J, Persson H, Ponikowski P,
Rauchhaus M, Voors A, Nielsen OW, Zannad F, Tavazzi L; Heart Failure Association of ESC (HFA). EURObservational Research Programme: the Heart Failure Pilot Survey (ESC-HF Pilot). Eur J Heart Fail 2010; 12: 1076-1084.

12. van Veldhuisen DJ, Maass AH, Priori SG, Stolt P, van Gelder IC, Dickstein K, Swedberg K. Implementation of device therapy (cardiac resynchronization therapy and implantable cardioverter defibrillator) for patients with heart failure in Europe: changes from 2004 to 2008. Eur J Heart Fail 2009; 11: 1143-1151.

13. Gheorghiade M, Flaherty JD, Fonarow GC, Desai RV, Lee R, McGiffin D, Love TE, Aban I, Eichhorn EJ, Bonow RO, Ahmed A. Coronary artery disease, coronary revascularization, and outcomes in chronic advanced systolic heart failure. Int J Cardiol 2011; 151: 69-75.

14. Meta-analysis Global Group in Chronic Heart Failure (MAGGIC). The survival of patients with heart failure with preserved or reduced left ventricular ejection fraction: an individual patient data meta-analysis. Eur Heart J 2012 33: 1750-1757

15. Lee DS, Gona P, Vasan RS, Larson MG, Benjamin EJ, Wang TJ, Tu JV, Levy D. Relation of disease pathogenesis and risk factors to heart failure with preserved or reduced ejection fraction: insights from the Framingham Heart Study of the National Heart, Lung, and Blood Institute. Circulation 2009; 119: 3070-3077.

16. Lourenço C, Saraiva F, Martins H, Baptista R, Costa S, Coelho L, Vieira H, Monteiro P, Franco F, Gonçalves L, Providęncia LA. Ischemic versus nonischemic cardiomyopathy - are there differences in prognosis? Experience of an advanced heart failure center. Rev Port Cardiol 2010; 30: 181-197.

17. Allen LA, Felker GM, Pocock S, McMurray JJ, Pfeffer MA, Swedberg K, Wang D, Yusuf S, Michelson EL, Granger CB; CHARM Investigators. Liver function abnormalities and outcome in patients with chronic heart failure: data from the Candesartan in Heart Failure: Assessment of Reduction in Mortality and Morbidity (CHARM) program. Eur J Heart Fail 2009; 11: 170-177.

18. Wedel H, McMurray JJ, Lindberg M, Wikstrand J, Cleland JG, Cornel JH, Dunselman P, Hjalmarson A, Kjekshus J, Komajda M, Kuusi T, Vanhaecke J, Waagstein F; CORONA Study Group. Predictors of fatal and non-fatal outcomes in the Controlled Rosuvastatin Multinational Trial in Heart Failure (CORONA): incremental value of apolipoprotein A-1, high-sensitivity C-reactive peptide and $\mathrm{N}$-terminal pro B-type natriuretic peptide. Eur J Heart Fail 2009; 11: 281-291.

19. Senni M, Parrella P, De Maria R, Cottini C, Böhm M, Ponikowski P, Filippatos G, Tribouilloy C, Di Lenarda A, Oliva F, Pulignano G, Cicoira M, Nodari S, Porcu M, Cioffi G, Gabrielli D, Parodi O, Ferrazzi P, Gavazzi A. Predicting heart failure outcome from cardiac and comorbid conditions: The $3 \mathrm{C}-\mathrm{HF}$ score. Int J Cardiol 2013; 163: 206-211.

20. Cleland JG, McMurray JJ, Kjekshus J, Cornel JH, Dunselman P, Fonseca C, Hjalmarson A, Korewicki J, Lindberg M, Ranjith N, van Veldhuisen DJ, Waagstein F, Wedel H, Wikstrand J; CORONA Study Group. Plasma concentration of amino-terminal pro-brain natriuretic peptide in chronic heart failure: prediction of cardiovascular events and interaction with the effects of rosuvastatin: a report from CORONA (Controlled Rosuvastatin Multinational Trial in Heart Failure). J Am Coll Cardiol 2009; 54: 1850-1859.

21. Masson S, Latini R, Anand IS, Barlera S, Angelici L, Vago T, Tognoni G, Cohn JN; Val-HeFT Investigators. Prognostic value of changes in $\mathrm{N}$-terminal pro-brain natriuretic peptide in Val-HeFT (Valsartan Heart Failure Trial). J Am Coll Cardiol 2008; 52: 997-1003.

22. Porapakkham P, Porapakkham P, Zimmet H Billah B, Krum H. B-type natriuretic peptide-guided heart failure therapy: A meta-analysis. Arch Intern Med 2010; 170: 507-514.

23. Kalogeropoulos A, Georgiopoulou V, Psaty BM, Rodondi N, Smith AL, Harrison DG, Liu Y, Hoffmann U, Bauer DC, Newman AB, Kritchevsky SB, Harris TB, Butler J; Health $A B C$ Study Investigators. Inflammatory markers and incident heart failure risk in older adults: the Health $A B C$ (Health, Aging, and Body Composition) study. J Am Coll Cardiol 2010; 55: 2129-2137.

24. Windram JD, Loh PH, Rigby AS, Hanning I, Clark AL, Cleland JG. Relationship of high-sensitivity C-reactive protein to prognosis and other prognostic markers in outpatients with heart failure. Am Heart J 2007; 153: 1048-1055.

25. Kozdağ G, Ertaş G, Teoman Kılıç T, Acar E, Ağir A, Sahin T, Cetin M, Bildirici U, Ural D. Elevated level of high-sensitivity C-reactive protein is important in determining prognosis in chronic heart failure. Med Sci Monit 2010; 16: CR156-161.

26. Yan RT, Fernandes V, Yan AT, Cushman M, Redheuil A, Tracy R, VogelClaussen J, Bahrami H, Nasir K, Bluemke DA, Lima JA. Fibrinogen and left ventricular myocardial systolic function: The Multi-Ethnic Study of Atherosclerosis (MESA). Am Heart J 2010; 160: 479-486. 
27. Barac A, Wang H, Shara NM, de Simone G, Carter EA, Umans JG, Best LG, Yeh J, Dixon DB, Devereux RB, Howard BV, Panza JA. Markers of inflammation, metabolic risk factors, and incident heart failure in American Indians: the Strong Heart Study. J Clin Hypertens (Greenwich) 2012; 14: 13-19.

28. Meluzin J, Spinarová L, Hude P, Krejcí J, Dusek L, Vítovec J, Panovsky R. Combined right ventricular systolic and diastolic dysfunction represents a strong determinant of poor prognosis in patients with symptomatic heart failure. Int J Cardiol 2005; 105: 164-173.
29. Chrustowicz A, Simonis G, Matschke K, Strasser RH, Gackowski A. Right ventricular dilatation predicts survival after mitral valve repair in patients with impaired left ventricular systolic function. Eur J Echocardiogr 2009; 10: 309-313.

30. Gustafsson F, Schou M, Videbaek L, Dridi N, Ryde H, Handberg J, Hildebrandt PR; Danish Heart Failure Clinics Network. Incidence and predictors of hospitalization or death in patients managed in multidisciplinary heart failure clinics. Eur J Heart Fail 2009; 11: 413-419. 